Ya. O. Liashok ${ }^{1}$, Dr. Sc. (Econ.), Assoc. Prof., orcid.org/0000-0002-7643-8485, O. I. Serhienko ${ }^{1}$, Cand. Sc. (Tech.), Assoc. Prof., orcid.org/0000-0002-3786-342X,

V. M. Kutserubov ${ }^{1}$, Cand. Sc. (Tech.), orcid.org/0000-0002-7979-8355,

O.P. Kohtieva ${ }^{1}$, orcid.org/0000-0001-7282-8243,

L.V. Serhienko ${ }^{2}$, Cand. Sc. (Tech.), orcid.org/0000-0002-4679-3435
1 - Donetsk National Technical University, Pokrovsk, Ukraine, e-mail: 2004831eo@gmail.com

2 - Institute for Physics of Mining Processes, Dnipro, Ukraine, e-mail: liana.sergienko@ukr.net

\title{
THE INFLUENCE OF THE MOISTURE ON THE PHYSICAL AND MECHANICAL PROPERTIES OF THE SANDSTONE (SEPARATE UNIT "KAPITALNA" COAL MINE", DONBAS)
}

Purpose. The influence of the moisture on the physical and mechanical properties of rock is evaluated by the experimental research in the laboratory.

Methodology. Laboratory studies of a coefficient of moisture capacity of the rock, determination of strain characteristics and strength, identification of the modulus of deformation and Poisson's ratio, statistical data processing based on correlation-regression analysis.

Findings. According to the laboratory studies, the dependence diagrams of the normal stresses from deformations for dry and wet rock samples were obtained. The correlation of stress limit on compression, modulus of elasticity and the coefficient of lateral deformation from the moisture content of the rock were obtained. In the course of the experiment, on the average, differences of mechanical characteristics of dry and wet states of the sandstone were established: stress limit on compressive is decreased almost twice; the modulus of elasticity is reduced by 4 times; the coefficient of lateral deformation is increased by 2.3 times.

Originality. The empirical dependences of mechanical properties from gravimetric moisture capacity of the sandstone sample were determined on the basis of the experiments in the laboratory. The regression power function was obtained for stress limit and modulus of elasticity, and for the coefficient of lateral deformation it was logarithmic. The coefficient of lateral deformation at the time of the destruction of some wet samples exceeded theoretically acceptable value of 0.5 .

Practical value. Obtained results can be applied in mathematical or numerical modeling of stress-strain state of the rock given consideration to the importance of the study of the influence of moisture on physical and mechanical markers and properties of rocks. It is possible to control stress-strain state around the roadways using the methods and the means of dewatering or hydro saturation as to coal seams and rocks.

Keywords: sandstone, rocks, physical and mechanical characteristics, deformation, stress, modulus of elasticity, coefficient of lateral deformation

Introduction. The stability of the rocks around the excavation and preparation workings is affected by the stress-strain state of the massif. Physical-mechanical properties perform a special influence on the formation of stress-deformed state of rocks around preparation workings. Change in these characteristics of the rocks makes it possible to control the stressstrain state of the massif. These physical and mechanical parameters are changed under the influence of external factors. One of these involves liquid and surface-active materials.

The saturation of the rocks with water contributes to their destruction at significantly reduced stresses than in the dry state. The reason for this is the penetration of the moisture into the smallest pores and queres, and in this case the water, under the influence of external pressure, tends to spread throughout the massif. Thus, water breaks the bond between the particles, widens the cracks and prevents them from closing. Moisture reduces the amount of surface energy of the solid. In this context the stresses are reduced which are necessary to break the bonds between atoms in the tip of a crack. The question of the influence the moisture of on the parameters of physical and mechanical properties of rocks is topical problem for today.

Literature review. The author [1] analyzed the literature on studies of the effect of mechanochemical effects on the filtration-capacitance and physico-mechanical properties of reservoir rocks. It is analyzed that at present the manifestation of mechanochemical effects in the field development has not

(C) Liashok Ya.O., Serhienko O.I., Kutserubov V.M., Kohtieva O.P., Serhienko L. V., 2020 been studied enough, or they concern clay rocks. Therefore, a wide range of different laboratory tests is needed, as well as the development of a mathematical model that would describe processes taking into account common geomechanical, geochemical and hydromechanical modeling.

Analysis of modern research studies on the influence of moisture on physical and mechanical properties of rocks showed that the fluid saturation affects the elasticity of rocks significantly. It has been found that prolonged moisture saturation significantly reduces the compression resistance. It is also proved that rocks water saturation has a greater variation of the average numbers of the coefficients of variation than in the dry state [2].

Authors [3] proposed a technique for the study of the nature of gas and water saturation of reservoir rocks in wells, where according to industrial-geophysical studies, geological observations during drilling and geological and technological studies, depth intervals with uncertain nature of fluid saturation are identified. Methodical methods for determination of absolute gas permeability, open porosity, effective porosity, phase gas permeability, gas saturation coefficient, as well as limit value of water saturation at which phase gas permeability is absent on the samples of sludge selected from such intervals, are developed. The results of research studies are presented about a determination of filtration-capacitance properties of sludge collectors on sludge samples, selected from intervals of depth of occurrence of thin-bedded sandy-clay thicknesses of neogene. The described method opens wide prospects in the justification of fluid saturation of reservoirs in cases when the methods of geophysical study of wells do not allow assessing the nature of their saturation exactly. 
Foreign studies [4, 5] also concern the physical and mechanical characteristics of rocks. In work [4], the authors carried out a study on variation of loading speed with uniaxial compression using samples of Sanjome andesite under different conditions of water saturation and strength increase with a tenfold increase in loading speed. Test results showed that the strength increases with decreasing water saturation. Testing of materials [5] included the hardness test on the compression and tensile on standard cylindrical specimens. Physical properties, such as fragility, are the main factors governing the formation of elastic and plastic zones. In general, the process of simulation and propagation of the crack and curve of force penetration of the indentation are simulated by numerical model. The performances are consistent with those which are observed in laboratory tests. In this study, the authors try to investigate the initiation and the propagation of cracks, as well as the generation of microcracks in the process of splitting and cutting with the Drucker-Prager strength criterion. The modes of rocks destruction of the numerical model are closely consistent with the results which are observed in laboratory tests.

The authors B. Vásárhelyi, M. Davarpanah [6] concluded that some mechanical parameters of rocks depend on the degree of saturation from water, but not the least dependence is conditioned by the composition of the rock itself. In the work [7], the studies concern the effect of initial damage on the strength and other mechanical properties and their changes from the nature of microcracks.

The author of [8], based on the experimental data, believes that the change of rocks elastic properties, due to the degree of humidity, is essentially nonlinear. At low levels of water saturation, the elastic properties show a rather rapid change - a decrease in Young's modulus and an increase in Poisson's ratio.

Article [9] presents the results of testing of the mechanical properties and pore structure of coal samples with different values of holding time in distilled water. Coal is obtained on the work surface where the explosion occurred. Exposure time changes the mechanical characteristics of the samples; this effect depends on the size (centimeter to nanometer). The results of numerical simulations and on-site tests in the coal mine have shown that pumping water can effectively soften the coal seam and relieve or transmit stresses. As the duration of the moisture action increases, the tension gradually decreases or redistributes. When the action time is 30 hours, the stress concentration in the area of action disappears and the stress in the plastic deformation zone decreases significantly.

The authors of the article [10] conducted an acoustic analysis of the destruction of rocks which are found in saturated and dry conditions in laboratory conditions. The correlation between water condition and acoustic emission signal is considered. A statistical dependence was observed between the amplitude buildup time and the average frequency, which shows that the characteristics of the cracks have a dependence on the presence or absence of the moisture. This method provides a new way of exploring the characteristics of rock massif disturbance and identifying patterns of disturbance.

Purpose. The purpose of the research is to evaluate the influence of moisture on the physical and mechanical properties of rock in laboratory conditions.

In order to achieve this, it is necessary to perform laboratory tests so as to determine:

- the coefficient of weight moisture of rock;

- mechanical characteristics of sandstone samples, taking into account the influence of moisture;

- conducting statistical processing of the obtained data using correlation-regression analysis.

Results. This article presents the results of laboratory studies of the influence of moisture on the physical and mechanical properties of sandstone $L_{1} S l_{1}$ of the "Kapitalna" mine of the State Enterprise "Myrnohradvuhillia" Donetsk coal basin.
The parameters of physical and mechanical characteristics for the dry and wet object of study are determined.

Cubic samples in size of $50 \times 50 \times 50 \mathrm{~mm}$ in the quantity of 11 pieces were prepared from the pieces of irregular sandstone with the help of stonecutter, with the value of total porosity equal to $4.68 \%$. Cubic shape samples were tested in a dry and saturated compression state using a P-50 hydraulic press with a maximum load of 50 tons. The measurement of longitudinal and transverse displacements was carried out by clock-type indicators, with a split price of $0.01 \mathrm{~mm}$. The entire process of loading and indication of the sensors was recorded on video. This made it possible to determine the deformation parameters at any time of the load on the research object.

The samples were dried in ovens at $120{ }^{\circ} \mathrm{C}$. The moisture content of the samples was determined by the difference between the mass of the saturated and the dry to the weight of the dry sample. The dried samples were weighed on a weighing scale to the nearest $0.01 \mathrm{~g}$, then placed in distilled water under a desiccator and connected to the compressor. Through this process forced extraction of gas mixture out of the sandstone pores takes place. The test data is presented in graphical form in Figs. 1-11.

Figs. 1, 2 show the load diagrams of dry (1) and wet (2) samples, the compression strength of which is 57.8 and 13.92 $\mathrm{MPa}$, respectively this is a decrease by almost 4 times in this case.

When the dry sample is loaded, brittle fracture occurs, plastic deformation is observed for wet specimens, when it is increased, the stress is almost unchanged, but it decreases approximately twice compared to the tensile strength itself.

Figs. 3, 4 show a diagram of the change in the linear parameters of the object during loading: for dry and wet respectively.

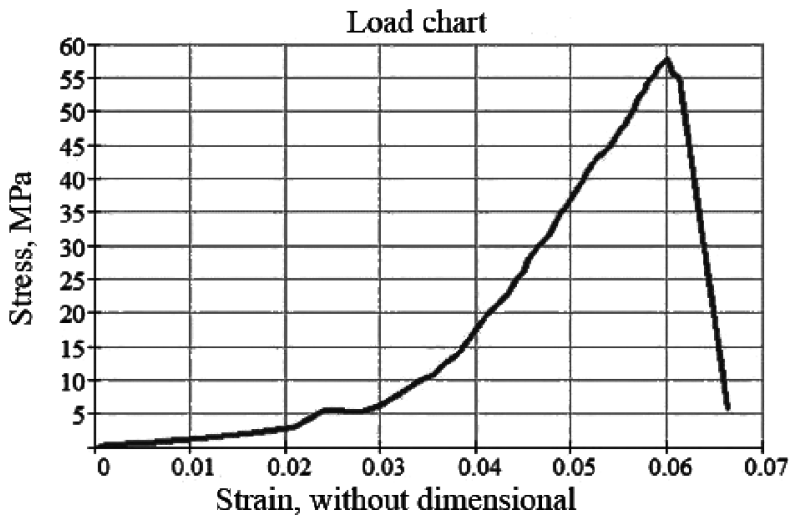

Fig. 1. Graph of dependency of the normal stresses on the dry sample deformation

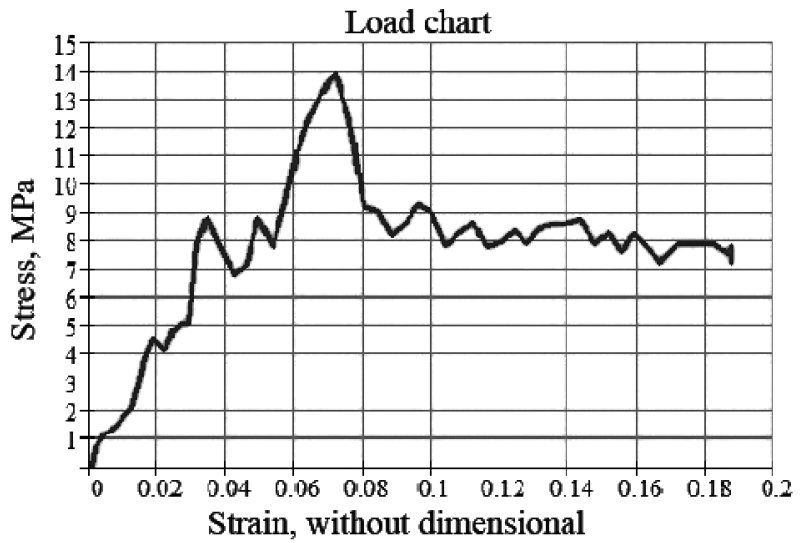

Fig. 2. Graph of dependency of the normal stresses on the deformation of the wet sample 
The value of the transverse deformation of the dried sample does not exceed $10 \%$ of the longitudinal one, and the value of the coefficient of transverse deformation does not exceed 0.12 - this is a characteristic of elastic deformation (Fig. 5, $a$ ). The lateral deformation for wet sample during its destruction is 0.38 , this exceeds the longitudinal one, the value of the coefficient can increase by more than 0.5 , and in some cases by more than 1.0 (Fig. 5, b). Such deformation is plastic.

The coefficient of transverse deformation (Fig. 6), at the time of the beginning of destruction (at maximum stress) of dry rock was 0.12 , and for wet rock it equals 0.38 (Fig. 7). It increases by 3 times.

The graphs in Figs. 6, 7 and 9 are constructed to determine the parameters of sandstone characteristics at maximum load.

Young's modulus of dry sandstone (Fig. 8, $a$ ) is increased (like a half-wave) - this can be characterized as compacting of the sample, and the wet sandstone begins to decrease in the form of a damping wave (Fig. 8, $b$ ). That is, this process of changing of the modulus of elasticity during loading of the wet sample has a wave attenuation character. In both cases, the initial value of the modulus of elasticity as the initial peak is observed.

Young's modulus at maximum stress is equal to the dry sample of $0.96 \mathrm{GPa}$ (Fig. 9, $a$ ), for the wet one $-0.19 \mathrm{GPa}$ (Fig. 9, b). Thus, till the moment of destruction for the dry sandstone modulus of elasticity increases its value, and for the wet sandstone, on the contrary - decreases. In this case the elastic modulus is reduced by 5 times.

Therefore, the saturation of sandstone with moisture influences its physical and mechanical properties and changes the deformation of elastic-fragile to elastic-plastic (Figs. 10, 11).

Destroyed dry sample after brittle fracture has left its cubic shape, and the wet sample has significantly deformed from the original shape.

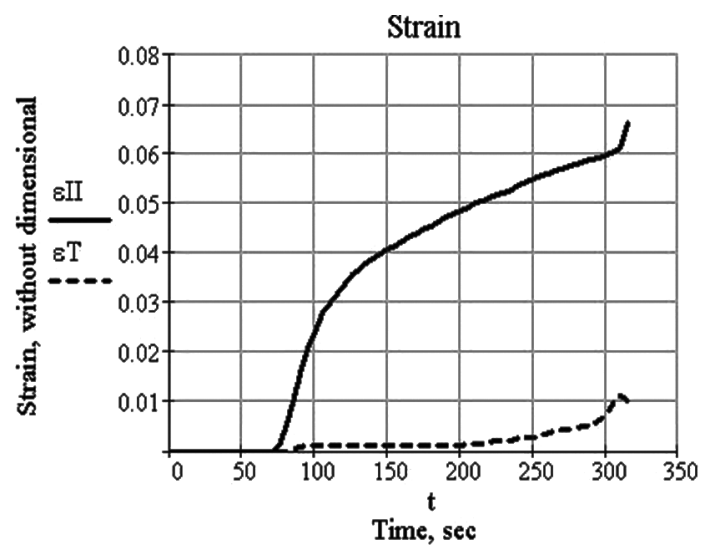

Fig. 3. Graph of variance over time under loading of the dry sample

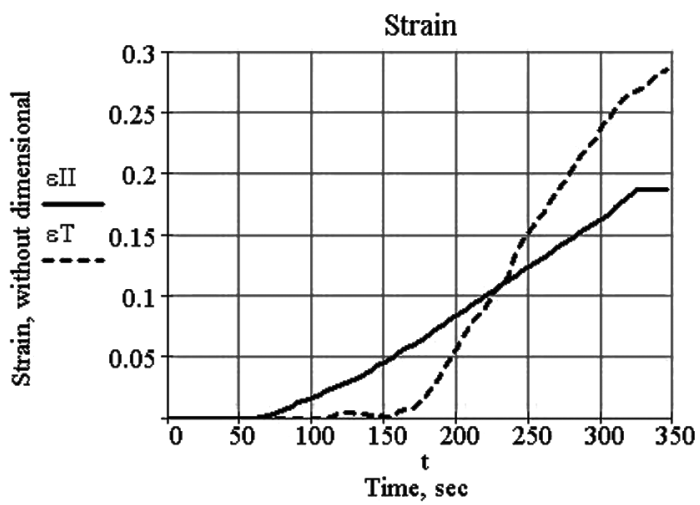

Fig. 4. Graph of variance over time under loading of the wet sample

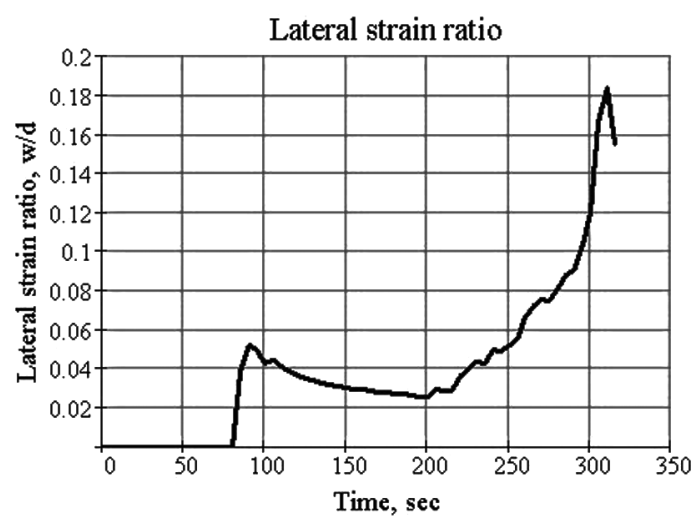

$a$

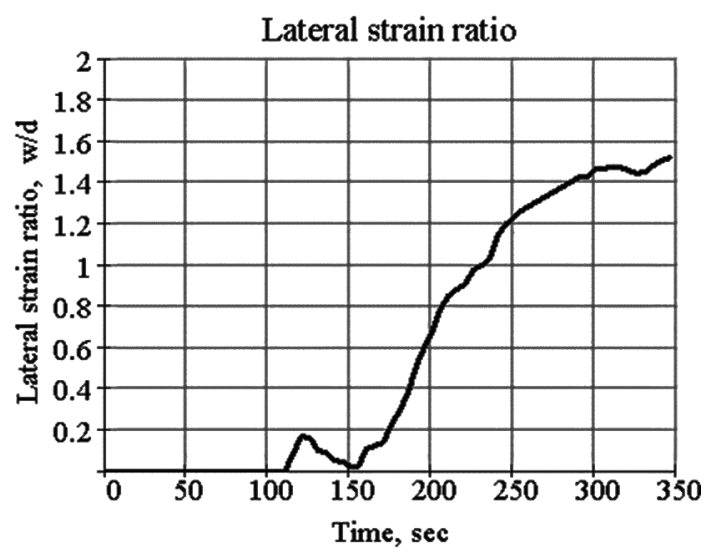

$b$

Fig. 5. The curve of change in the coefficient of lateral deformation under the influence of loading on the sample: $a-$ dry; $b-$ wet

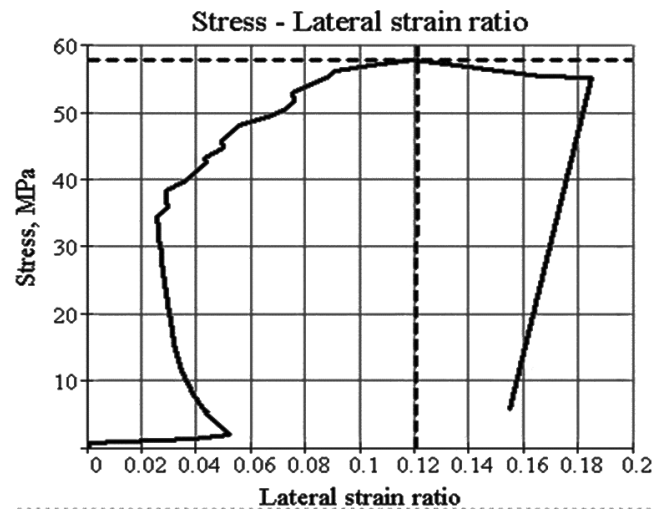

Fig. 6. Dependency graph of stress and transverse deformation coefficient of dry sandstone sample

After studying the mechanical properties of dry and wet cubic models, empirical dependencies were obtained: the compressive strength, Young's modulus, and the transverse deformation coefficient from their moisture capacity (Figs. 12, 14, 16).

Dependence of stress limit on compression from the moisture content of the sandstone has the form of a power function

$$
\sigma_{c}(w)=-27.6426 \cdot w^{0.4333}+56.0057,
$$

or

$$
\sigma_{c}(w)=\sigma_{c . o}-\frac{\sigma_{c . o}}{2} \cdot w^{0.4333},
$$




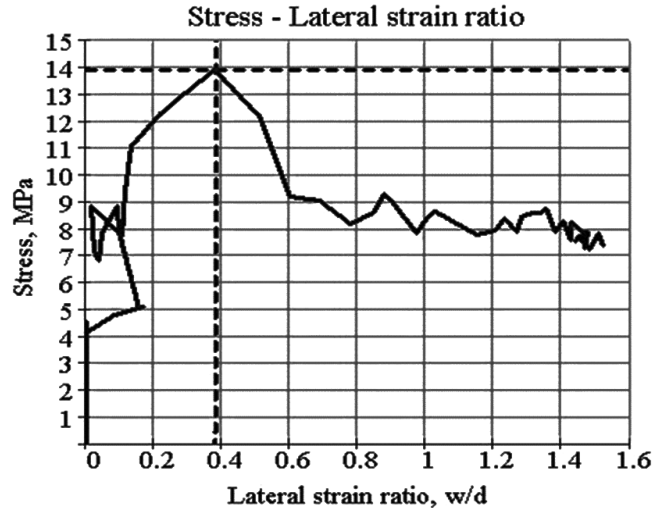

Fig. 7. Dependency graph of stress and transverse deformation coefficient of wet sandstone sample

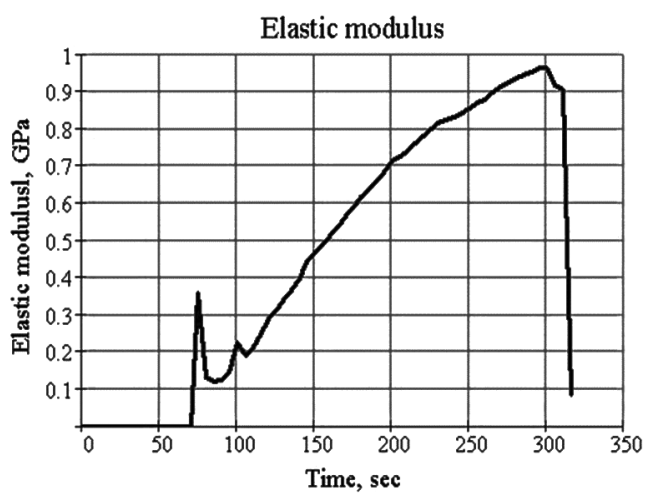

a

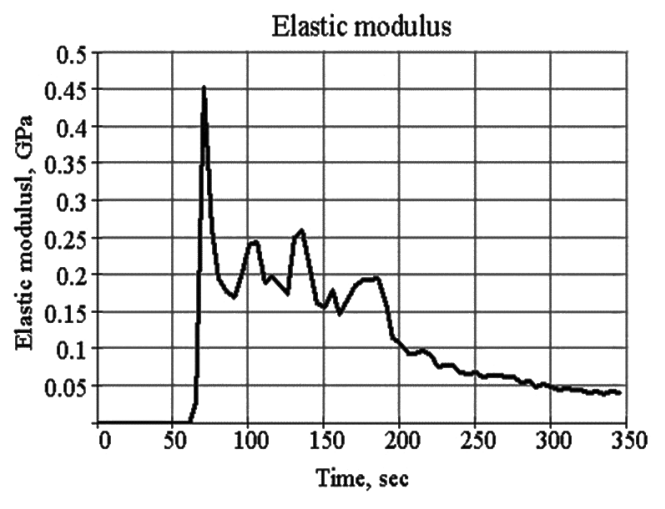

$b$

Fig. 8. Curve of change of elasticity modulus under the action of loading on sandstone:

$a-d r y ; b-w e t$

where $\sigma_{c . o}$ is the stress limit of the dry sample of the compression of rock, $\mathrm{MPa}$

The dependence of the modulus of elasticity on the moisture content is

$$
E(w)=-0.8289 \cdot w^{0.4585}+1.4686,
$$

or

$$
E(w)=E_{o}-0.56 \cdot w^{0.4585},
$$

where $E_{o}$ is the modulus of elasticity of dry sample of rock, $\mathrm{GPa}$.

Dependences of the coefficient of transverse deformation on the moisture content for this sandstone has the form of a logarithmic function

$$
\mu(w)=0.6533 \cdot \ln (w+5.2728)-0.8858 .
$$
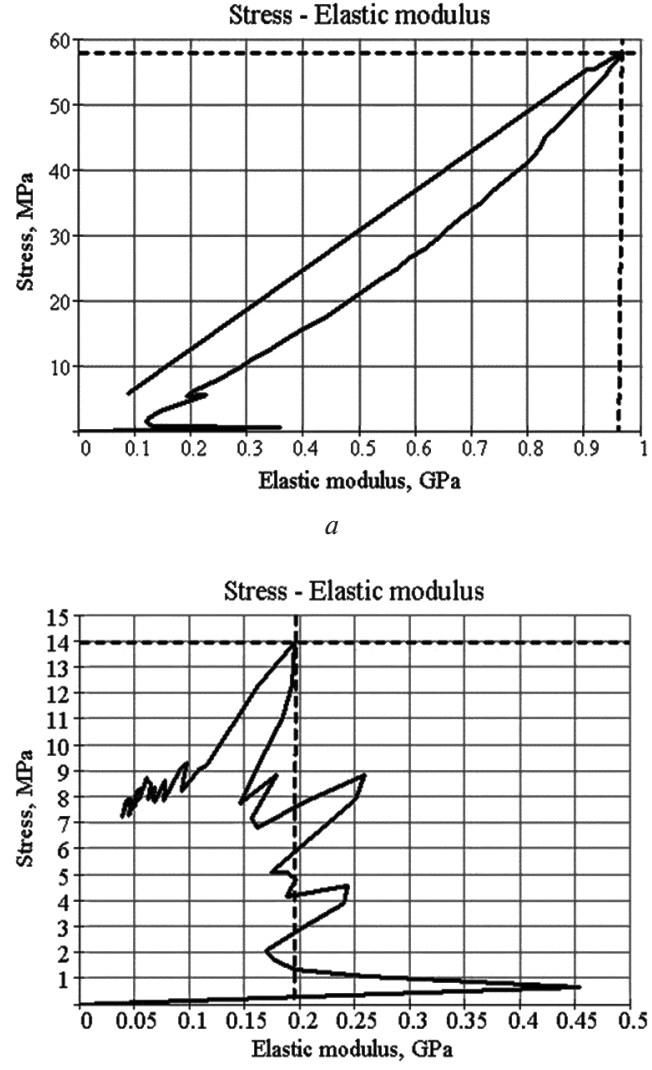

Fig. 9. Curve of change of elasticity modulus under the action of loading on sandstone:

$a-d r y ; b-w e t$

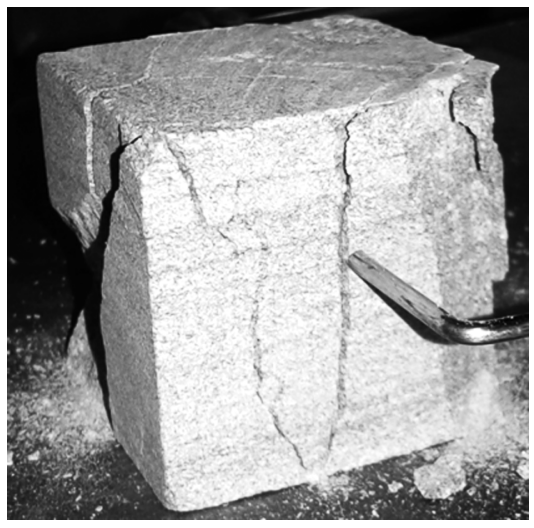

Fig. 10. Photo of the destroyed dry sample

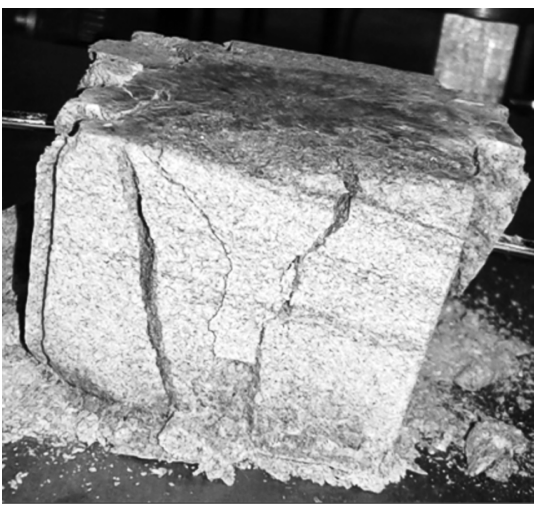

Fig. 11. Photo of the destroyed wet sample 


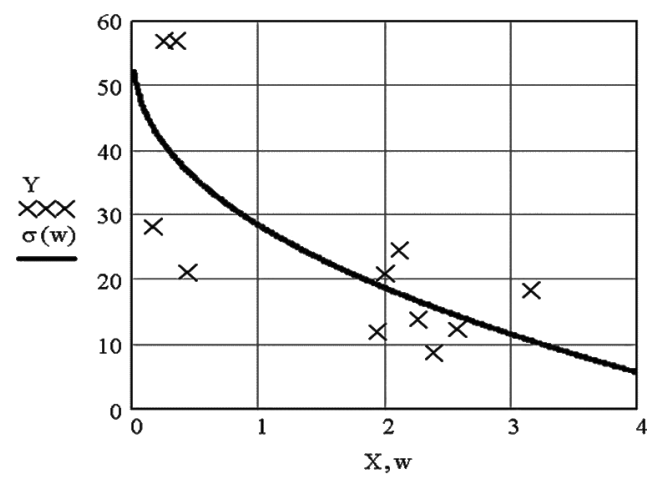

Fig. 12. Graph of dependency of stress limit on compression from the moisture content

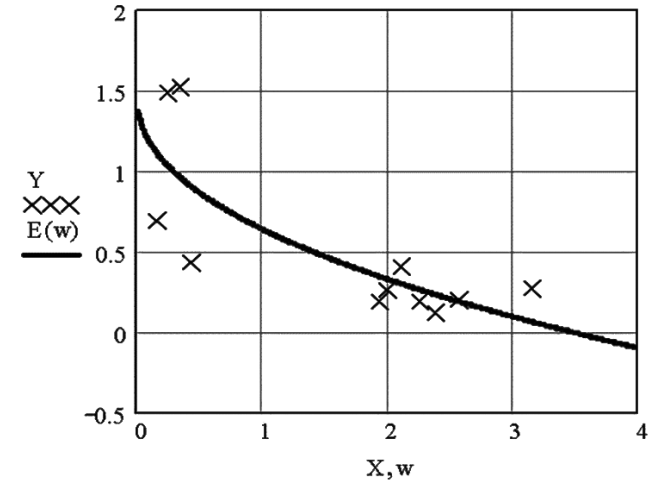

Fig. 13. Graph of dependency of elasticity modulus on moisture content

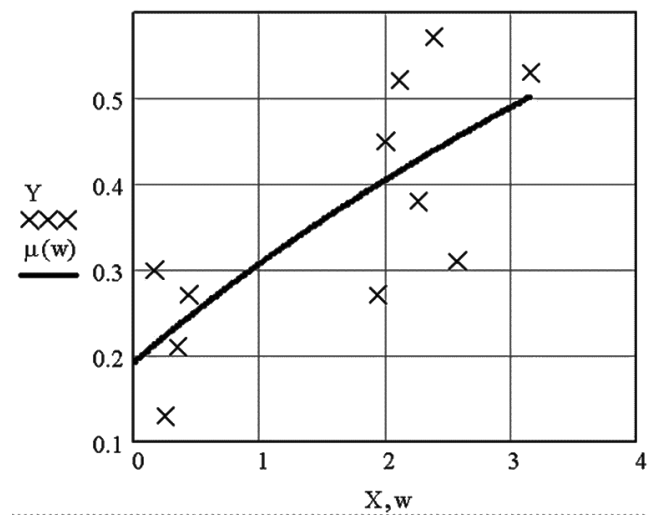

Fig. 14. Graph of dependency of the coefficient of transverse deformation on the moisture content

Table

Parameters of correlation-regression analysis

\begin{tabular}{|l|c|c|c|}
\hline \multicolumn{1}{|c|}{ Parameters } & $\sigma_{c}(w)$ & $E(w)$ & $\mu(w)$ \\
\hline $\begin{array}{l}\text { Coefficient of correlation for } \\
\text { linear dependence }\end{array}$ & 0.5224 & 0.5779 & 0.5409 \\
\hline $\begin{array}{l}\text { Coefficient of determination } \\
\text { for nonlinear dependence }\end{array}$ & 0.5406 & 0.5946 & 0.5677 \\
\hline The minimum value & $8.71 \mathrm{MPa}$ & $0.12 \mathrm{GPa}$ & 0.13 \\
\hline The maximum value & $56.96 \mathrm{MPa}$ & $1.52 \mathrm{GPa}$ & 0.57 \\
\hline Average value & $24.88 \mathrm{MPa}$ & $0.52 \mathrm{GPa}$ & 0.35 \\
\hline Asymmetry & 1.6694 & 1.6640 & 1.3033 \\
\hline Excess & 0.0532 & 0.1302 & -1.1708 \\
\hline
\end{tabular}

The correlation parameters of the three functions listed above are summarized in Table.

Conclusions. As a result of laboratory tests, the following results were obtained:

1. Mechanical properties under moistening of the sandstone, the moisture content of which reaches a range of $2-3 \%$, have the following average values:

- stress limit on compression is reduced by almost 2 times;

- the modulus of elasticity is decreased by 4 times;

- the coefficient of lateral deformation is increased by 2.3 times

2. The empirical dependencies are obtained: stress limits on compression, modulus of elasticity and transverse deformation coefficient from their moisture content with the lowest determination coefficient 0.54 . In contrast to the linear dependence, the nonlinear dependence is obtained which characterizes a closer link

As a corollary to this, it should be noted that the obtained data of the mechanical properties of the sandstone under the influence of the moisture, can be taken into account in the mathematical modeling of the stress-deformed state of the massif, in particular for sandstones, in the conditions of SU "Kapitalna" Mine Myrnohradvuhillia" Donetsk coal basin.

\section{References.}

1. Mikhailov, N., \& Popov, S. (2015). Experimental and theoretical study of influence of mechanochemical effects on porosity, permeability, elastic and strength properties of reservoir rocks. Georesources. Geoenergetics. Geopolitics, $1-26$.

2. Yalanskyi, A.A., Sapunova, I. O., Slashchov, A. I., \& Novikov, L.A. (2014). Substantiation of initial parameters for modeling geomechanical processes in problems on estimation of safety of maintenance of mine workings. Heotekhnichna mekhanika, 119, 282-295.

3. Loktev, A. V., Nesterenko, M. Y., Vladyka, V. M., Paiuk, S. O., Balatskyi, R. S., \& Zderka, T. V. (2014). Methodical questions for determining the character of fluid saturation of reservoir rocks in thin-layer sandy-clay section. Naukovyi Visnyk IFNTUNH, 2(37), 7-15.

4. Hashiba, K., Fukui, K., \& Kataoka, M. (2019). Effects of water saturation on the strength and loading-rate dependence of andesite. International Journal of Rock Mechanics and Mining Sciences, 117, 142-149. https://doi.org/10.1016/j. ijrmms.2019.03.023.

5. Liu, X., Wu, L., Zhang, Y., Liang, Z., Yao, X., \& Liang, P. (2019). Frequency properties of acoustic emissions from the dry and saturated. Environmental Earth Sciences, 2-17.

6. Balázs Vásárhelyi, \& Morteza Davarpanah (n.d.). Influence of Water Content on the Mechanical Parameters of the Intact Rock and Rock Mass. Periodica Polytechnica Civil Engineering, 1-6. https://doi.org/10.3311/PPci.12173.

7. Jun Peng, Louis Ngai, Yuen Wong, Guang Liu, \& Cee Ing Teh (2018). Influence of initial micro-crack damage on strength and micro-cracking behavior of an intrusive crystalline rock. Bulletin of Engineering Geology and the Environment. https://doi.org/10.1007/s10064-018-1317-3.

8. Sukniov, S. V. (2016). Determination of static modulus of elasticity and Poisson's ratio of rocks with changes in humidity. Gornyi informatsyonno-analiticheskii biuleten, 7 , 108-116.

9. Liu, X., Xu, G., Zhang, C., Kong, B., Qian, J., Zhu, D., \& Wei, M. (2017). Time Effect of Water Injection on the Mechanical Properties of Coal and Its Application in Rockburst Prevention in Mining. Energies, 10, 1783. https://doi. org/10.3390/en10111783.

10. Liu, X., Wu, L., Zhang, Y., Liang, Z., Yao, X., \& Liang, P. (2019). Frequency properties of acoustic emissions from the dry and saturated rock. Environmental Earth Sciences, 78, 67. https://doi.org/10.1007/s12665-019-8058-x. 


\section{Вплив вологи на фізико-механічні властивості пісковику (ВП «Шахта «Капітальна», Донбас)}

\author{
Я. О. Ляшок ${ }^{1}$, О. І. Сергієнко ${ }^{1}$, В. М. Куцерубов ${ }^{1}$, \\ О. П. Когтєва ${ }^{1}$, Л. В. Сергієнко ${ }^{2}$
}

1 - Донецький національний технічний університет, м. Покровськ, Україна, е-mail: 200483leo@gmail.com 2 - Інститут фізики гірничих процесів, м Дніпро, Україна, е-mail: liana.sergienko@ukr.net

Мета. Оцінити в лабораторних умовах вплив вологи на фізико-механічні властивості гірської породи.

Методика. Лабораторне дослідження коефіцієнта вагової вологоємності гірської породи, визначення в лабораторних умовах деформаційних характеристик i міцності, встановлення модуля деформації й коефіцієнта поперечної деформації, статистична обробка даних з використанням кореляційно-регресійного аналізу.

Результати. За даними лабораторних випробувань побудовані графіки залежностей нормальних напружень від деформацій для сухого й вологого зразків гірської породи відповідно. Отримана кореляція межі міцності на стиск, модуля пружності й коефіцієнта поперечної деформації від вологоємності гірської породи. У ході експерименту, у середньому, встановлені відмінності механічних характеристик сухого й вологого стану пісковика: межа міцності на стиск зменшується майже вдвічі, модуль пружності зменшується в 4 рази, коефіцієнт поперечної деформації збільшується у 2,3 рази.

Наукова новизна. На основі проведених експериментів у лабораторних умовах встановлені емпіричні залежності механічних властивостей від вагової вологоємності зразка пісковику. Для межі міцності й модуля пружності отримана регресна степенева функція, а для коефіцієнта поперечної деформації - логарифмічна. Коефіцієнт поперечної деформації на момент руйнування деяких вологих зразків перевищував теоретично припустиме значення 0,5 .

Практична значимість. Ураховуючи важливість дослідження впливу вологи на фізико-механічні показники та властивості гірських порід, отримані результати можна застосовувати при математичному або чисельному моделюванні напружено-деформованого стану гірського масиву. Використовуючи способи й засоби зневоднення або гідронасичення як вугільних пластів, так і прилеглих порід, можливе управління їх напружено-деформованим станом навколо виробок.

Ключові слова: пісковик, гірські породи, фізико-механічні характеристики, деформація, напруження, модуль пружності, коефіцієнт поперечної деформаціі

\section{Влияние влаги на физико-механические свойства песчаника (ОП «Шахта «Капитальная», Донбасс)}

\section{Я. А. Ляшок ${ }^{1}$, А. И. Сергиенко ${ }^{1}$, В. М. Куцерубов ${ }^{1}$,} О. П. Когтева ${ }^{1}$, Л. В. Сергиенко 2

1 - Донецкий национальный технический университет, г. Покровск, Украина, e-mail: 200483leo@gmail.com

2 - Институт физики горных процессов, г. Днепр, Украина, e-mail: liana.sergienko@ukr.net

Цель. Оценить в лабораторных условиях влияние влаги на физико-механические свойства горной породы.

Методика. Лабораторные исследования коэффициента весовой влагоемкости горной породы, определение в лабораторных условиях деформационных характеристик и прочности, определение модуля деформации и коэффициента поперечной деформации, статистическая обработка полученных данных с использованием корреляционно-регрессионного анализа.

Результаты. По данным лабораторных испытаний построены графики зависимостей нормальных напряжений от деформаций для сухого и влажного образцов горной породы соответственно. Получена корреляция предела прочности на сжатие, модуля упругости и коэффициента поперечной деформации от влагоемкости горной породы. В ходе эксперимента, в среднем, установлены различия механических характеристик сухого и влажного состояния песчаника: предел прочности на сжатие уменьшается почти вдвое, модуль упругости уменьшается в 4 раза, коэффициент поперечной деформации увеличивается в 2,3 раза.

Научная новизна. На основе проведенных экспериментов в лабораторных условиях установлены эмпирические зависимости механических свойств от весовой влагоемкости образца. Для предела прочности и модуля упругости получена регрессивная степенная функция, а для коэффициента поперечной деформации - логарифмическая. Коэффициент поперечной деформации в момент разрушения некоторых влажных образцов превышал теоретически допустимое значение 0,5 .

Практическая значимость. Учитывая важность изучения влияния влаги на физико-механические показатели и свойства горных пород, полученные результаты можно применять при математическом или численном моделировании напряженно-деформированного состояния горного массива. Используя способы и средства обезвоживания или гидронасыщения как угольных пластов, так и прилегающих пород, возможно управление их напряженно-деформированным состоянием вокруг выработок

Ключевые слова: песчаник, горные породы, физико-механические характеристики, деформация, напряженность, модуль упругости, коэффициент поперечной деформации

Recommended for publication by S. V. Podkopaiev, Doctor of Tchnical Sciences. The manuscript was submitted 23.05.19. 